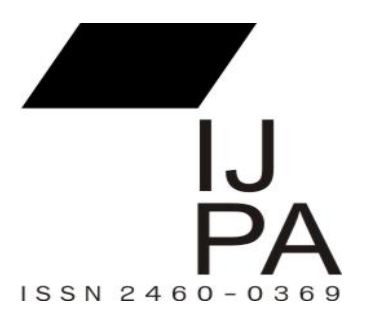

\title{
PEMBANGUNAN INDONESIA DALAM PANDANGAN AMARTYA SEN
}

\author{
Dra. Sri Henny Indarti, M.Si \\ Program Studi Ilmu Administrasi Publik \\ Fakultas Ilmu Ssosial dan Ilmu Politik \\ Universitas 17 Agustus 1945 Jakarta \\ srihennyindarti@gmail.com
}

\begin{abstract}
Abtsract: Balancing of materialistic and non-materialistic factors for human welfare, hard concern for the distribution of opportunities within society was important thing for realize development. Increasing income can be used as a part of development without reliable indicator of freedom as substantial factor. There's 3 process who must be reached by all of one, such as increasing change of distribution basic needs, increasing living standart by increase income, increasing education quality and the concern for cultural of values. This article just talking about that it's not eazy to a realized but we have to learn by Amartya Sen perspective.
\end{abstract}

Keywords: Development, Social Change, Capability, Amartya Sen, Perspective

\begin{abstract}
Abstrak: Keseimbangan faktor materi dan non materi untuk kesejahteraan manusia, penekanan terhadap kesempatan distribusi dalam masyarakat merupakan hal penting untuk merealisasikan pembangunan. Peningkatan income tidak dapat dijadikan bagian dari pembangunan tampa merealisasikan indikator kebebasan sebagai faktor substansi, disamping peningkatan kualitas dan memperhatikan nilai-nilai budaya.
\end{abstract}

Kata kunci: Pembangunan, Sosial, Kapabilitas Amartya Sen 


\section{Pendahuluan}

Pembangunan slalu dihubungkan dengan suatu perubahan kondisi kepada situasi dan kondisi yang lebih baik dari sebelumnya. Hal tersebut tidak sepenuhnya salah bahkan cenderung memiliki konotasi positif, yaitu suatu pertumbuhan dan masa depan yang lebih baik. Berbagai interpretasi juga dilontarkan dengan berbagai argument yang mampu menggiring pada pemikiran bahwa pembangunan slalu membawa kebaikan. Namun era globalisasi dan komunika mampu seolah membenarkan pemahaman tersebut. Kadang peningkatan pendapatan per kapita atau Gross Domestic Pro duct (GDP) selalu dapat dijadikan ukuran pembangunan, padahal tak jarang kesenjangan sosial pun sering mengiringi pembangunan apabila yang terjadi justru ketidakmerataan pendistribusiannya. Kemiskinan misalnya, menjadi salah satu bentuk kesenjangan yang ada di tengah-tengah proses pembangunan. Hal ini apabila ekonomi yang menjadi aspek dalam melihat pembangunan. Hal tersebut juga disebabkan industrialisasi, perkembangan teknologi yang terjadi selain proses modernisasi masyarakat, namun bagi yang tidak memiliki akses terhadap aset-aset produksi serta keterbatasan pilihan dan kesempatan, maka terjadilah kemiskinan, kelaparan, malnutrisi, keterpinggiran budaya, dan sisi-sisi negatif lainnya yang padakenyataannya ada dan menjadi fenomena nyata di tengah pertumbuhan ekonomi yang dibilang pesat.

Lalu apa sebenarnya kapabilitas sebagai faktor penting yang harus ada dalam proses pembangunan, sementara pertumbuhan ekonomi yang slalu menjadi ikon dalam pembangunan, cenderung tidak dapat berdiri sendiri tampa menciptakan kebebasan, pemerataan distribusi dan Hak Asasi Manusia. Ada beberapa hal yang ingin penulis angkat dalam tulisan ini adalah untuk mengetahui apa saja unsur dari pembangunan suatu negara dengan pandangan Amartya Sen dengan teori kapabilitasnya dalam pembangunan sepertinya sangat tepat untuk menjadi dasar teori dalam pembahasan masalah tersebut. 


\section{Dasar Pemikiran}

Konsep Kapabilitas Amartya Sen Sen mendefinisikan "kapabilitas" sebagai (Michael P.Todaro, 2003:24)

"kebebasan yang dimiliki seseorang dalam arti pilihan functioning, dengan fitur-fitur personal yang dimilikinya (perubahan karakteristik menjadi functioning), dan kontrol yang dimilikinya terhadap komoditi...".

Penekanan terhadap kesehatan dan pendidikan, dan menyebut negaranegara yang memiliki tingkat pendapatan yang tinggi tetapi memiliki standar kesehatan dan pendidikan yang rendah sebagai kasus "pertumbuhan tanpa pembangunan”. Pendapatan riil memang sangat penting, tetapi untuk mengkoversikan karakteristik komoditi menjadi fungsi yang sesuai, dalam banyak hal yang penting, jelas membutuhkan kesehatan dan pendidikan selain pendapatan. Demikian yang disampaikan Amartya Sen (Michael P.Todaro, 2003:25)

Belian melanjutkan bahwa konsep Kapabilitas berfungsi mencakup tiga aspek kunci (Amartya Sen, 2003) yaitu: Pertama adalah kecukupan, yang meliputi kecukupan atas kebutuhan-kebutuhan dasar.Kedua adalah harga diri, yang mencakup dorongan dari diri sendiri untuk maju, menghargai diri sendiri, jati diri sebagai negara dan masyarakat timur dan lain sebagainya.Ketiga adalah kebebasan dari sikap menghamba. Komponen kebebasan manusia melingkupi segenap komponen antara lain: kebebasan politik, keamanan diri pribadi, kepastian hukum, kemerdekaan berekspresi, partisipasi politik dan pemerataan kesempatan. Jadi pembangunan tampa diiringi dan mempertimbangkan komponen kebebasan, hanyalah akan menjadi suatu bencana, karena hal tersebut akan menciptakan perubahan sosial yang tidak diharapkan bahkan menghambat proses pembangunan itu sendiri.

\section{Pembahasan}

Pembangunan yang didasarkan pada kebebasan dan demokrasi akan menghasilkan kesejahteraan sosial, sehingga dapat terhindar dari kemiskinan massal atau paling tidak dapat pulih kembali dalam waktu yang lebih cepat, yang pada akhirnyapun akan terjadi perubahan sosial. seperti apa yang tercantum dalam UUD 1945, pasal 33 ayat (1) yang berbunyi: Perekonomian disusun sebagai usaha 
bersama berdasar atas azas kekeluargaan; Ayat (2) yang berbunyi: Bumi, air dan kekayaan alam yang terkandung di dalamnya dikuasai oleh Negara dan dipergunakan untuk sebesar-besarnya kemakmuran rakyat; Ayat (3) yang berbunyi: Perekonomian nasional diselenggarakan berdasar atas demokarasi ekonomi dengan prinsip kebersamaan, efisiensi berkeadilan, berkelanjutan, berwawasan lingkungan, kemandirian, serta dengan menjaga keseimbangan kemajuan dan kesatuan ekonomi nasional.

Pembangunan seharusnya proses perluasan kebebasan (freedom) melalui perwujudan hak-hak dasar manusia (entitlement) di satu pihak dan pembinaan kapabilitas manusia (human development) di lain pihak. mengedepankan kebebasan sebagai tujuan dan istrumen pembangunan. Kategori keberhasilan pembangunan terutama pada manusia sebagai subyeknya yang memiliki kebebasan yang semakin meningkat. Demikian yang disampaikan Sen.

Dalam pembahasan mengenai berbagai paradigma yang mencari jalan kearah pembangunan yang berkeadilan, maka perlu diketengahkan pula teori pembangunan yang berpusat pada rakyat. Era pasca industri menghadapi kondisikondisi yang sangat berbeda dari kondisi-kondisi era industri dan menyajikan potensi-potensi baru yang penting guna memantapkan pertumbuhan dan kesejahteraan manusia, keadilan dan kelestarian pembangunan itu sendiri (Korten, 1984). Paradigma ini memberi peran kepada individu bukan sebagai objek, melainkan sebagai pelaku yang menetapkan tujuan, mengendalikan sumber daya, dan mengarahkan proses yang mempengaruhi kehidupannya. Pembangunan yang berpusat pada rakyat menghargai dan mempertimbangkan prakarsa rakyat dan kekhasansetempat.

Pembangunan sosial sebagai suatu paradigm dan berbagai pandangan di dalamnya adalah paradigma pembangunan manusia. Menurut paradigma pembangunan manusia, tujuan utama dari pembangunan adalah menciptakan suatu lingkungan yang memungkinkan masyarakatnya untuk menikmati kehidupan yang kreatif, sehat dan berumur panjang. Pertumbuhan produksi dan pendapatan hanya merupakan alat saja, sedangkan tujuan akhir pembangunan harus manusianya sendiri. 
Memperluas pilihan-pilihan manusia (Ul Haq, 1985) sebagai tujuan pokok pembangunan yang mempunyai dua sisi, pertama, pembentukan kemampuan manusia seperti tercermin dalam kesehatan, pengetahuan dan keahlian yang meningkat, dan kedua, penggunaan kemampuan yang telah dipunyai untuk bekerja, untuk menikmati kehidupan atau untuk aktif dalam kegiatan kebudayaan, sosial, dan politik. Paradigma pembangunan manusia yang disebut sebagai sebuah konsep yang holistik mempunyai 4 (empat) unsur penting, yakni peningkatan produktivitas, pemerataan kesempatan, kesinambungan pembangunan, dan pemberdayaan manusia.

Tujuan pembangunan nasional mengalami pegeseran dari pembangunan ekonomi semata-mata, menuju pembangunan yang merefleksikan komplementaritas antara pembangunan ekonomi dan pembangunan nasional. Seperti munculnya gagasan pembangunan berkelanjutan yang erat kaitannya dengan kesejahteraan yang semakin terus meningkat dari generasi ke generasi. Dalam konsep tersebut, pemakaian dan hasil penggunaan sumber daya alam dan lingkungan yang merusak sumbernya, tidak dihitung sebagai kontribusi terhadap pertumbuhan tetapi sebagai pengurangan asset.

\section{Perubahan Sosial}

Pembangunan sosial didefinisikan sebagai perubahan sosial yang direncanakan, di arahkan untuk meningkatkan kesejahteraan penduduk secara menyeluruh, dalam kaitan pembangunan ekonomi dan kelestarian lingkungan. Saat ini distorsi terhadap konsep pembangunan sosial telah banyak muncul. Beberapa negara dan lembaga keuangan internasonal telah memfokuskan kepada penghapusan kemiskinan bukan pembangunan sosial. Pada hal kemiskinan adalah hanya sebagian dari permasalahan. Hal ini telah menjurus pada pelaksanaan kebijakan yang hanya berorientasi kepada penanganan sebagian masyarakat. Sebagian besar para ahli dalam pembangunan sosial menganjurkan penanganan yang lebih strategis dan bersifat komprehensif, termasuk pembangunan masyarakat, tanggung jawab sosial dari perusahaan atau korporasi, memperkuat 
masyarakat sipil dan menjamin hak asasi manusia dan hak sosial, sepanjang arus dan dimensi kehidupan.

\section{Makna dan Definisi Pembangunan}

Pembangunan adalah upaya untuk memperluas kebebasan nyata yang dinikmati oleh rakyat, sehingga perluasan kebebasan dipandang sebagai tujuan utama pembangunan. Bukti empiris menunjukkan bahwa kebebasan ekonomi dan politik saling memperkuat, sehingga peluang sosial di bidang pendidikan dan kesehatan melengkapi peluang seseorang untuk berperan serta dalam ekonomi dan politik serta mendorong inisiatif guna mengatasi berbagai kekurangannya.

Pandangan konvensional tentang pembangunan adalah berdasarkan pada pendapatan per-kapita sebuah negara merupakan unsur yang sangat penting untuk dijadikan tolak ukur kemajuan sebuah negara, sebab sangat mempengaruhi negara dalam melaksanakan pembangunan sosial dan ekonomi seperti: membangun fasilitas pendidikan dan fasilitas kesehatan, mampu menciptakan kondisi politik dan masyarakat sipil yang tentram seperti kebebasan masyarakat dalam menyampaikan aspirasinya, sehingga kondisi ini akan menciptakan sebuah masyarakat yang bebas.

Istilah pembangunan (Development) dalam bukunya Amartya Sen yang berjudul Development as Freedom, bahwa embangunan itu sangat identik dengan yang namanya pertumbuhan pendapatan perkapita nasional (GNP), kemudian pendapatan personal penduduk yang dibarengi dengan indutrialisasi, perkembangan teknologi di sebuah negara dan terakhir moderenisasi masyarakat (Amartya, 2000:3). Pembangunan harus direkonseptualisasi sebagai memajukan kebebasan dasar manusia dan meniadakan sumber-sumber ketidakmerdekaan seperti kemiskinan, kesempatan ekonomi yang minim, pengabaian sistematis, atau unsur-unsur lain yang membuat orang kurang memiliki kesempatan atau pilihan untuk menjalankan gairah perkembangannya.

Istilah pembangunan (Development)dalam bukunya Amartya Sen (Amartya, 2000:3) yang berjudul "Development as Freedom", bahwa "pembangunan adalah proses negosiasi dan renegosiasi aturan sosial yang 
berjalan untuk melindungi atau menambah kemerdekaan instrumental". Dalam situasi ideal, lembaga masyarakat sipil yang tidak terkekang akan membantu mempromosikan kemerdekaan individual melalui bekerjasama dengan negara atau pasar yang "freedom enhancing" dan menentang yang "freedom limiting" (Amartya, 2000:3). Istilah Pembangunan disini ditujukan agar sebuah negara dapat menciptakan tatanan sosial yang lebih baik dan memenuhi kebutuhan rakyatnya, sehingga rakyat dapat hidup sejahtera. Sebuah pembangunan akan dinilai baik jika pembangunan itu dapat membebaskan manusia dari masalahmasalah keterbelakangan, sehingga akan menciptakan kehidupan yang sejahtera. Sebaliknya pembangunan akan dinilai buruk jika pembangunan itu justru semakin menciptakan keterbelakangan umat manusia di sebuah Negara. UNDP (1994) mendefinisikan pembangunan sebagai proses yang meningkatkan kesempatan orang untuk memilih. Pendidikan menghasilkan pengetahuan, skill, dan kapabilitas yang memungkinkan seseorang memiliki lebih banyak pilihan dan kemerdekaan. Dan pemerintahan serta aturan konstitusional adalah bagian yang penting bagi kemerdekaan dan pilihan individual, dan dianggap sebagai parameter yang penting dengan apa pembangunan dinilai (United Nations, 2008:18-19)

Secara umum, pembangunan dapat diartikan pula sebagai suatu upaya terkoordinasi untuk menciptakan alternatif yang lebih banyak secara sah kepada setiap warga negara untuk memenuhi dan mencapai aspirasinya yang paling manusiawi. Pembangunan merupakan suatu proses, yakni proses untuk mencapai kemajuan. Proses membutuhkan input sumber daya untuk ditransformasikan menjadi sebuah hasil. Jika input tidak memadai, tentu akan menghasilkan output yang tidak optimal. Menurut Siagian(1994), pembangunan sesungguhnya suatu usaha atau rangkaian usaha pertumbuhan dan perubahan berencana dan dilakukan secara sadar oleh bangsa,negara dan pemerintah menuju modernitas dalam rangka pembinaan bangsa (nation building). Secara umum, pembangunan dapat diartikan pula sebagai suatu upaya terkoordinasi untuk menciptakan alternatif yang lebih banyak secara sah kepada setiap warga negara untuk memenuhi dan mencapai aspirasinya yang paling manusiawi.

Sumitro mendefinisikan pembangunan sebagai (Sumitro, 1994) : 
"suatu transformasi dalam arti perubahan struktur ekonomi. Perubahan struktur ekonomi diartikan sebagai perubahan dalam struktur ekonomi masyarakat yang meliputi perubahan pada perimbangan keadaan yang melekat pada landasan kegiatan ekonomi dan bentuk susunan ekonomi”.

Menurut Tjokrowinoto bahwa batasan pembangunan yang nampaknya bebas dari kaitan tata nilai tersebut dalam realitasnya menimbulkan interpretasiinterpretasi yang seringkali secara diametrik bertentangan satu sama lain sehingga mudah menimbulkan kesan bahwa realitas pembangunan pada hakikatnya merupakan self project reality (Moeljarto, 1997)

Di lain sisi, Kartasasmita menyatakan, pembangunan adalah (Ginandjar, 1996: 15)

"usaha meningkatkan harkat martabat masyarakat yang dalam kondisinya tidak mampu melepaskan diri dari perangkap kemiskinan dan keterbelakangan. Membangun masyarakat berarti memampukan atau memandirikan mereka".

Suatu kenyataan fisik sekaligus tekad suatu masyarakat untuk berupaya sekeras mungkin melalui serangkaian kombinasi proses sosial, ekonomi, dan institusional, demi mencapai kehidupan yang serba lebih baik (Michael P.Todaro, 2003:8). Karena itu, proses pembangunan di semua masyarakat paling tidak harus memiliki tiga tujuan inti, yaitu: pertama adalah peningkatan ketersediaan serta perluasan distribusi berbagai macam barang kebutuhan hidup yang pokok seperti pangan, sandang, papan, kesehatan dan perlindungan keamanan. Kedua yaitu peningkatan standar hidup yang tidak hanya berupa peningkatan pendapatan, tetapi juga meliputi penambahan penyediaan lapangan kerja, perbaikan kualitas pendidikan, serta peningkatan perhatian atas nilai-nilai kultural dan kemanusiaan yang kesemuanya itu tidak hanya untuk memperbaiki kesejahteraan materiil, melainkan juga menumbuhkan harga diri pada pribadi dan bangsa yang bersangkutan. Ketiga, perluasan pilihan-pilihan ekonomis dan sosial bagi setiap individu serta bangsa secara keseluruhan. Sen memaknai pembangunan sebagai kebebasan. Artinya ukuran keberhasilan pembangunan; Pertama, tingkat ketimpangan pendapatan; Kedua, penurunan jumlah kemiskinan;Ketiga, penurunan tingkat pengangguran. (Michael P.Todaro, 2003:8) 
Pembangunan sebagai proses pembuatan kebijakan (agency) dan juga pencapaian dampak sosial (struktur). Berbeda dengan cara pandang pembangunan sebagai "out put per head", yang mempertimbangkan proses yang ada, kesempatan yang ada, makna instrinsik dan derivatif serta peran konstruktif dari kesempatan yang ada. Seperti yang diuraikan Sen, proses perluasan kebebasan terdapat dua perspektif, yaitu sebagai tujuan utama (primary end) dan sarana pokok ( principal means). Artinya pembangunan dilihat sebagai tujuan utama yang juga disebut peran konstitutif, dimana hal ini terkait dengan pentingnya menilai pembangunan sebagai kebebasan substantif dalam memperkaya kehidupan manusia. Kemampuan untuk mencegah kelaparan,kemiskinan, kekurangan gizi dan kematian pada usia dini. Sementara itu, Sen juga menegaskan perlunya memahami pembangunan sebagai perluasan kebabasan yang dilihat sebagai sebuah sarana pokok, menjadi kemampuan yang bersifat substansif. Dalam hal ini pembangunan dinilai sebagai sebuah sarana, disebut sebagai kebebasan instrumental, dimana kebebasan akan sangat efektif untuk dapat berkontribusi dalam penciptaan pertumbuhan ekonomi.

Pembangunan dipahami sebagai sebuah sarana, kebebasan instrumental dapat dilihat dari beberapa aspek yang saling melengkapi satu sama lain, seperti: kebebasan politik; kesempatan-kesempatan ekonomi; peluang-peluang sosial, jaminan keterbukaan dan perlindungan keamanan (Amartya Sen, 2000:36-38)

Hal ini juga dimaksudkan sebagai pemerataan kepada setiap individu yang berhakmendapatkan penghidupan yang cukup atas pemenuhan kebutuhan dasar sehingga pembangunan menjadi penting dalam memberikan jaminan bagi setiap golongan masyarakat, jika pembangunan diartikan sebagai upaya pencapaian Hak Asasi Manusia. Mekanisme mencapai mencapai HAM dengan melalui penguatan konstitusi dalam hal mengatur kebijakan tentang pembagian pada kelompok mayoritas dan minoritas memiliki independensi (saling tidak intervensi) dan terlebih dalam mencegah konflik kemudian digerakkan pembangunan dibidang sosial danekonomi dikarenakan agar sektor-sektor tersebut menciptakan independensi istimewa bagi negara, bahkan kelompok minoritas tidak pernah dapat menjadi lebih superior (mengambil alih kekuasaan) mereka tetap bisa 
menjamin sumber-sumber bagi kelangsungan kesejahteraan mereka, sehingga keistimewaan-keistimewaan tertentu dan bermartabat, kemudian kekuatan mereka dalam mengakses ekonomi secara efektif melindungi mereka dari aturan kelompok mayoritas, kelompok masyarakat yang independen adalah yang berbasis ekonomi dengan independensi tersebut tentu dapat mengimbangi kelompok mayoritas dalam bidang politik.

\section{Perpektif Pembangunan}

Pandangan banyak ahli ekonomi pembangunan terhadap pembangunan ekonomi masih diwarnai kontroversi antara pertumbuhan ekonomi dan pemerataan pembangunan. Masih adanya kontroversi antara mana yang lebih dahulu untuk dilakukan dan dicapai, pertumbuhan ekonomi atau pemerataan pembangunan. Kontroversi tersebut muncul disebabkan karena penerapan strategi pembangunan ekonomi yang mengacu pada pertumbuhan (growth) dan pemerataan (equity) belum menunjukkan hasil yang memuaskan.

Berbagai perspektif pembangunan tersebut merujuk kepada gelombang besar terminologi: minimalisasi peran pemerintah dan maksimalisasi peran swasta, seperti tulisan Osborne-Gaebler-Plastrik dalam Reinventing Government (1993) dan Banishing Bereaucracy (1997) hingga Amartya Sen dalam Development as Freedom (2000). Gelombang privatisasi pembangunan tersebut muncul seiring pendekatan good governance, pemberdayaan, gerakan Lembaga Swadaya Masyarakat (LSM), pendekatan partisipatoris hingga masyarakat madani (Andi Harun, 2007:15-16)

Melihat elemen-elemen pembangunan tersebut, maka sebenarnya pembangunan mencakup jauh lebih banyak aspek. Bahwa pembangunan menuntut pendapatan per kapita yang lebih tinggi adalah fakta yang tidak bisa dibantah. Namun, pembangunan yang mereduksi nilai-nilai dasar kemanusiaan dan menempatkan pertumbuhan ekonomi sebagai satu-satunya indikator pembangunan justru mereduksi makna pembangunan itu sendiri.

Dalam Development as Freedom (2000) telah membantah pandangan yang hanya menilai pembangunan hanya dengan peningkatan pendapatan 
perkapita.tersebut. Dalam pandangannya, berbagai kondisi, selain kekurangan pangan, seperti kurangnya nutrisi, buta huruf, tiadanya kebebasan sipil dan hakhak berdemokrasi, diskriminasi, pengidapan penyakit, dan berbagai bentuk perampasan hak-hak milik (entitlement) pribadi adalah bentuk-bentuk kemiskinan yang menciptakan penderitaan. Demikian definisi baru yang disampaikan Sen mengenai pembangunan sebagai kebebasan (development as freedom). (Dawan Rahardjo, 2001:14-15)

Sebagian orang berhasil menikmati kemakmuran, namun kualitas hidup masih tetap jauh dari jangkauan banyak orang. Pertumbuhan ekonomi yang pesat terjadi di sejumlah negara dalam 2 dasawarsa terakhir, namun banyak orang lain tidak mendapatkan keuntungan dari kemajuan tersebut. Dalam banyak situasi, kebijakan pembangunan ternyata lebih menguntungkan vested interest kaum elite, sehingga dengan demikian tidak mempromosikan investasi yang memadai dalam modal manusia dan modal alam, yang sangat esensial bagi pertumbuhan berbasis luas. Kualitas faktor-faktor yang memberikan kontribusi bagi pertumbuhan menuntut perhatian fundamental apabila kemiskinan ingin dikurangi dan kualitas hidup yang lebih baik dapat dicapai oleh semua orang. (Vinod Thomas, 2001:16)

Pentingnya redistribusi aset non-fisik, seperti kesehatan dan pendidikan. Oleh sebab itu, masalah paling besar dalam soal redistribusi aset adalah bagaimana meluaskan dan memperbaiki akses pendidikan bagi mayoritas penduduk yang kurang mampu. Redistribusi aset non-fisik inilah yang masih menjadi pertanyaan mendasar dalam proses pembangunan di Indonesia (M.Chatib Basri, 2004:17)

\section{Pembangunan Di Indonesia}

Indonesia dengan Trilogi Pembangunan. Delapan jalur pemerataan yang dimaksud adalah pemerataan,dalam hal: pemenuhan kebutuhan pokok rakyat banyak, berupa pangan, sandang dan perumahan;kesempatan memperoleh pendidikan dan pelayanan kesehatan; pembagian pendapatan;kesempatan kerja;kesempatan berusaha;kesempatan berpartisipasi dalam pembangunan, 
khususnya bagi generasi muda dan kaum wanita;penyebaran pembangunan; dan kesempatan memperoleh keadilan (Syahyuti, 2006:166-167).

Di DKI Jakarta besaran garis kemiskinan mencapaiRp331.169 perkapita per bulan, sementara di Papua Rp259.128. Data di level nasional merupakan penjumlahan penduduk miskin di seluruh provinsi, sehingga jumlah penduduk miskin di Indonesia pada Maret 2010 sebesar 31,02 juta (13,33 persen dari total penduduk) dengan garis kemiskinan sebesar Rp211.726 per kapita per bulan. Pada bulan Maret 2011BPS akan kembali melakukan pengumpulan data Susenas dan hasil penghitungan penduduk miskin akan dirilis tanggal 1 Juli 2011. Salah satu data kemiskinan yang mengundang polemik panjang adalah data kemiskinan bulan Maret 2006.BPS mengumumkan jumlah penduduk miskin naik dari 35,1 juta (16,0\%) pada Februari 2005 menjadi 39,30 juta (17,8\%) pada Maret 2006 karena kenaikan harga BBM. Data BPS menunjukkan, persentase pengeluaran rumah tangga (RT) untuk makanan pada 2004 mencapai 54,59 persen menurun menjadi 51,37 persen pada 2005 dan naik lagi menjadi 53,01 persen pada 2006. Pengeluaran ini untuk makanan ini erat kaitannya dengan distribusi pendapatan masyarakat. Seiring dengan itu, 40 persen populasi berpendapatan rendah juga fluktuatif pada tahun 2004, 2005 dan 2006, yang masing-masing 20,80 persen, 18,81 persen dan 19,75 persen.

Sementara pengeluaran RT untuk non-makanan pada 2004, 2005 dan 2006 masing-masing 45,42 persen, 48,63 persen, dan 46,99. Data ini menunjukkan bahwa pengeluaran konsumsi RT di Indonesia lebih besar dibandingkan pengeluaran non-makanan. Data ini mencirikan bahwa Indonesia memang masih negara sedang berkembang, dimana pengeluaran makanan (autonomous consumtion) lebih besar dibanding dengan pengeluaran non-makanan (liburan, dll).

Indonesia memiliki banyak Tantangan yang dimiliki Indonesia untuk memenuhi kebutuhan dasar hidup masyarakat, terutama jika dilihat sebegai negara berkembang, khususnya kebutuhan sandang, pangan dan papan. Indonesia dihadapkan pada masalah dan tantangan sebagai berikut.: Pertama, menjaga 
kegiatan ekonomi nasional yang pro rakyat agar dapat mendorong turunnya angka kemiskinan. Termasuk di dalamnya ialah menjaga kondisi ekonomi makro agar dapat mendorong kegiatan ekonomi riil yang berpihak pada penanggulangan kemiskinan. Upaya menjaga inflasi agar tidak menurunkan daya beli masyarakat miskin, termasuk menjaga harga kebutuhan pokok utama seperti beras, menjadi tantangan serius yang harus dihadapi.Kedua, meningkatkan akses masyarakat miskin terhadap pelayanan dasar seperti pendidikan, kesehatan, dan gizi; termasuk keluarga berencana, serta akses terhadap infrastruktur dasar seperti sanitasi dan air bersih. Ini merupakan tantangan yang tidak ringan, mengingat secara geografis Indonesia merupakan negara yang sangat luas.Ketiga, melibatkan masyarakat miskin untuk dapat meningkatkan kapasitasnya sendiri dalam menanggulangi kemiskinan. Pengalaman menunjukkan bahwa melibatkan serta meningkatkan kapasitas mereka sebagai penggerak dalam penanggulangan kemiskinan terbukti sangat efektif.Keempat, belum berkembangnya sistem perlindungan sosial, baik yang berbentuk bantuan sosial bagi mereka yang rentan maupun sistem jaminan sosial berbasis asuransi terutama bagi masyarakat miskin.Kelima, adanya kesenjangan yang mencolok antar berbagai daerah (inter-regional disparity). Kesenjangan tersebut dapat dilihat dari tingkat kedalaman kemiskinan yang sangat berbeda antardaerah satu dengan lainnya. Ditinjau dari proporsinya, tingkat kemiskinan di provinsi-provinsi di luar Jawa lebih tinggi dibandingkan dengan proporsi tingkat kemiskinan di Jawa. Selain itu kesenjangan dapat dilihat pula dari perbedaan angka indeks pembangunan manusia yang mencolok antardaerah, termasuk antar perkotaan dan perdesaan.

Kesenjangan ini dibuktikan oleh data BPS 2004, 2005 dan 2006. 40 persen populasi ternyata hanya menikmati 20,80 persen, 18,81 persen dan 19,75 persen pendapatan. Tidak sebanding dengan 20 persen penduduk kaya yang bisa menikmati pendapatan 42,07 persen (2004), 44,78 persen (2005), dan 42,15 persen (2006). Itu sebabnya Gini Ratio Indonesia masih bertengger di angka 0,32 (2004), 0,36 (2005) dan 0,33 (2006).

Khusus untuk pendidikan dan kesehatan, Laporan MDGs 2007 menunjukkan walaupun angka partisipasi kasar tingkat SD/MI maupun SMP/MTs menunjukkan perbaikan, tetapi bila dilihat dari tingkat kelompok pengeluaran rumah tangga, maka terdapat perbedaan antara kelompok rumah tangga miskin 
dan non-miskin. Pada kelompok pengeluaran terbawah (kuantil 20\% terbawah, Q1), APK SD/MI tahun 1995 adalah 104,88 persen dan mencapai 108,92 persen pada tahun 2006. Data tahun 1995 hingga 2006 menunjukkan indikasi bahwasanya APK SD/MI untuk kelompok pengeluaran terbawah ternyata berkembang lebih baik dari APK SD/MI untuk golongan pengeluaran teratas. Peristiwa yang sama juga terjadi pada APK SMP/MTs antara tahun 1995 hingga 2006. APK SMP/MTs tahun 1995 pada kelompok pengeluaran terbawah tercatat 44,39 persen dan menjadi 70,78 persen pada tahun 2006. Intinya, perbaikan kesejahteraan rumah tangga berpengaruh pada akses terhadap pendidikan, terutama bagi keluarga yang mempunyai anak usia sekolah SD dan SMP.

Aspek kebebasan yang dilihat partisipasi politik dan pemerataan kesempatan memperoleh informasi terpampang pada ilustrasi berikut ini. Akses terhadap informasi dapat dilihat dari 3 indikator di atas. Persentase penduduk 10 tahun ke atas yang mendengar radio hanya mencapai 40,26 persen pada 2006, menurun dibandingkan 2003 yang mencapai 50,29 persen. Sejalan dengan hal tersebut, masyarakat yang bisa menikmati/menonton televisi mencapai 85,86 persen meningkat dibandingkan tahun 2003 yang hanya mencapai 84,94 persen. Hal ini sejalan dengan peningkatan pemanfaatan listrik rumah tangga yang mencapai 87,76 persen pada 2006. Dari sisi partisipasi politik (pemilihan gubernur dan wakil gubernur), catatan Jaringan Pemantau Pemilu untuk Rakyat (JPPR) menunjukkan, dari tahun 2005, 2006, 2007 dan 2008 hanya mencapai rentang 60-70 persen, dengan prosentase sebesar 41 persen. Sementara untuk pemilihan bupati dan walikota di 165 kabupaten/kota pada tahun yang sama mencapai 44 persen dengan tingkat partisipasi sebesar 70-80 persen. Hal ini menunjukkan tingkat partisipasi politik masih relatif rendah, tidak sampai 50 persen. Kerendahan tingkat partisipasi politik ini disinyalir berkaitan erat dengan beberapa faktor politik, diantaranya kedewasaan berdemokrasi, sistem politik yang belum bisa mendorong masyarakat untuk terlibat secara aktif dalam proses politik, kepastian hukum, korupsi yang dilakukan oleh politikus dan lain sebagainya. 


\section{Kesimpulan}

Dapat disimpulkan pandangan Sen mengenai pembangunan adalah, Pertama, pembangunan yang didasarkan pada kebebasan dan demokrasi akan menghasilkan kesejahteraan sosial, sehingga dapat terhindar dari kemiskinan massal atau paling tidak dapat pulih kembali dalam waktu yang lebih cepat. Kedua, Pembangunan seharusnya melalui proses perluasan kebebasan (freedom) melalui perwujudan hak-hak dasar manusia (entitlement) di satu pihak dan pembinaan kapabilitas manusia (human development) di lain pihak mengedepankan kebebasan sebagai tujuan dan istrumen pembangunan. Kategori keberhasilan pembangunan terutama pada manusia sebagai subyeknya yang memiliki kebebasan yang semakin meningkat. Sementara untuk kasus Indonesia sebagai negara berkembang dapat disimpulkan diperlukan faktor pemerataan pembangunan dan kesejahteraan rakyat agar pembangunan merata, dengan mendorong pertumbuhan yang berkualitas, menjaga stabilitas ekonomi makro dan mendorong kegiatan ekonomi agar berpihak kepada penanggulangan kemiskinan. Perlu juga upaya untuk mendorong penciptaan kesempatan kerja dan berusaha yang lebih luas agar mampu menjangkau masyarakat miskin. Hal penting lain adalah meningkatkan akses masyarakat miskin terhadap pendidikan, kesehatan dan gizi termasuk pelayanan keluarga berencana, serta infrastruktur dasar seperti air bersih dan sanitasi. Terakhir dengan memperluas perlindungan sosial dengan meningkatkan bantuan sosial dan membangun system perlindungan sosial yang memadai serta meningkat pemberdayaan politik masyarakat sebagai control terhadap jalannya proses pembangunan.

\section{Daftar Pustaka}

Dawan Rahardjo, 2001. Ekonom Dari Shantiniketan, pengantar dalam Amartya Sen, Masih Adakah Harapan Bagi Kaum Miskin (terj. On Ethics and Economics), Penerbit Mizan, Jakarta

Michael P. Todaro \& Stephen C. Smith, 2003. Pembangunan Ekonomi di Dunia Ketiga, edisi kedelapan, Erlangga, Jakarta

Moeljarto Tjokrowinoto, 1997. Politik Pembangunan, Sebuah Analisis Konsep, Arah dan Strategi, Penerbit Tirai Wacana, Yogyakarta 
Sumitro Djojohadikusumo, 1994. Perkembangan Pemikiran Ekonomi Dasar Teori Ekonomi Pertumbuhan dan Ekonomi Pembangunan, Pustaka LP3ES, Jakarta

Vinod Thomas, et.al, 2001. The Quality of Growth (Kualitas Pertumbuhan), PT. Gramedia Pustaka Utama, Jakarta 